\title{
Corrosion Behaviour of the Fe-Cr-V-Ru System in Reducing Acid Solution
}

\author{
Sie Chin TJONG
}

Physical Metallurgy Division, Council for Mineral Technology, Randburg 2125, Republic of South Africa

(Received on October 2, 1989; accepted in the final form on January 26, 1990)

\begin{abstract}
The corrosion behaviours of $\mathrm{Fe}-24 \mathrm{Cr}-6 \mathrm{~V}$ alloys containing $0.12,0.24$, and $0.35 \mathrm{wt} \%$ Ru additions in non-oxidizing acid solutions were studied by means of the electrochemical and Auger electron spectroscopic techniques. The weight-loss measurements show that the addition of $\mathrm{Ru}$ to the $\mathrm{Fe}-24 \mathrm{Cr}-6 \mathrm{~V}$ alloy in the composition range 0.12 to $0.35 \%$ is very effective in increasing the corrosion resistance of this alloy in a $5 \% \mathrm{H}_{2} \mathrm{SO}_{4}$ acid solution at 70 and $98^{\circ} \mathrm{C}$, respectively. Also, the addition of $\mathrm{Ru}$ to the $\mathrm{Fe}-24 \mathrm{Cr}-6 \mathrm{~V}$ alloy is found to be beneficial in the concentration range 0.24 to $0.35 \%$ range when the alloy is exposed to $5 \% \mathrm{HCl}$ solution at 70 and $98^{\circ} \mathrm{C}$, respectively. AES results reveal that the spontaneously passivated films formed on the $\mathrm{Fe}-24 \mathrm{Cr}-6 \mathrm{~V}-\mathrm{Ru}$ alloy system in $5 \% \mathrm{HCl}$ solution at $25^{\circ} \mathrm{C}$ are enriched in chromium and vanadium but depleted in ruthenium.
\end{abstract}

KEY WORDS: cathodic modified alloy; non-oxidizing acid; spontaneous passivation; vanadium; potentiodynamic scan; weight-loss; Auger electron spectroscopy; depth-profile.

\section{Introduction}

The ferritic stainless steels have certain attractive applications in chloride-containing environments. They exhibit superior resistance to stress corrosion cracking and good resistance to pitting and crevice corrosion. The localized corrosion resistance of the stainless steels is generally known to derive from high chromium contents, and substantial amounts of molybdenum. However, the ductility and toughness of the ferritic stainless steels depend significantly on the Gr content, and also on carbon and nitrogen interstitials, ${ }^{\text {") }}$ as $\mathrm{C}$ and $\mathrm{N}$ impurities tend to promote the precipitation of chromium carbonitride during the welding process. Thus conventional ferritic stainless steels such as AISI 430 have found little application because of low ductility and sensitization problems. With the introduction of advanced melting techniques such as argon-oxygen decarburization (AOD) or vacuum-oxygen decarburization (VOD), it has been possible to reduce the amounts of $\mathrm{C}$ and $\mathrm{N}$, respectively.

It is well known that addition of Mo to the ferritic stainless steels increases their corrosion resistance in chloride solutions. The addition of Mo results in a substantial decrease of the critical current density for passivation, and an increase of the pitting potential thereby extending the passive potential range. ${ }^{2)}$ The beneficial effect of Mo depends on the Gr content and hence Mo interacts synergistically with $\mathrm{Cr}$. However, the role of Mo by which it exerts its beneficial effect remains obscure. ${ }^{3}$ ) On the other hand, $\mathrm{V}$ has been considered as a potential substitute for Mo because Mo is not widely distributed around the world. Vanadium has also been reported to exhibit beneficial effect on the pitting resistance of austenitic and ferritic stainless steels, ${ }^{4-6)}$ and this element has been added in the conventional stainless steel designated as SCR-3.7)
Davies and Robinson indicated that $V$ is not as effective alloying element as Mo in improving the pitting resistance of low interstitial ferritic stainless steels. ${ }^{6}$ In non-oxidizing acid solutions, Biefer reported that the addition of $\mathrm{V}$ up to $2 \%$ leads to a decrease in the critical current density for passivation of the ferritic 430 stainless steel in $5 \%$ sulphuric acid solution. ${ }^{8)}$ Recently, Goetz et al. suggested that the beneficial influence of addition of $\mathrm{V}$ on passivation and pitting resistance of the ferritic $\mathrm{Fe}-\mathrm{Cr}$ alloys in $1 \mathrm{M} \mathrm{HCl}$ solution was attributed to a decrease in the iron activity of the alloys. ${ }^{9}$ )

It has been shown that combining $\mathrm{Fe}-\mathrm{Cr}$ based alloys with platinum group metal (PGM) additions is very effective for increasing the corrosion resistance of these alloys in non-oxidizing acid environments. ${ }^{10,11)}$ The improved corrosion resistance results from the accumulation of PGM on the alloy surface during the initial period of an active dissolution and a subsequent potential shift from an active to the passive region. The beneficial effect of PGM alloying depends on the concentration added, and also on the hydrogen overvoltage characteristics of each of the PGMs. The effect of the addition of various PGMs on the corrosion resistance of ferritic $\mathrm{Fe}-\mathrm{Cr}-\mathrm{Mo}$ alloys was studied by Streicher. ${ }^{12,13)} \mathrm{He}$ reported that $\mathrm{Fe}-28 \mathrm{Cr}-4 \mathrm{Mo}$ alloys become passivated in boiling sulphuric acid solution when PGMs were present in the alloy in excess of a certain minimum concentration. From the economic point of view, $\mathrm{Ru}$ costs about one seventh as much as $\mathrm{Pt}$, and half as much as $\mathrm{Pd} .{ }^{14)}$ Hence $\mathrm{Ru}$ appears to be more cost effective alloying element than the other PGMs. Furthermore, combining $\mathrm{Fe}-\mathrm{Gr}$ based alloys with $\mathrm{Ru}$ has been shown to be more effective than $\mathrm{Pd}$ in enhancing the corrosion resistance of these alloys in non-oxidizing acid solutions. ${ }^{15,16)}$ 
Surface analytical techniques such as Auger electron spectroscopy (AES) and electron spectroscopy for chemical analysis (ESCA) have been used extensively to study the surface chemistry and chemical bonding of the elemental constituents in the passive film formed on the $\mathrm{Fe}-\mathrm{Cr}$ and $\mathrm{Fe}-\mathrm{Cr}-\mathrm{Mo}$ alloys. ${ }^{17-19)}$ However, little information is available on the application of these techniques to the self-passivation of $\mathrm{Fe}-\mathrm{Cr}$ alloys containing PGM additions. The present work attempts to reduce the $\mathrm{Cr}$ content in the $\mathrm{Fe}-\mathrm{Cr}$ alloy by partial substitution of $\mathrm{Cr}$ with $\mathrm{V}$, as a high $\mathrm{Cr}$ content is detrimental to the toughness of the alloy. ${ }^{1)}$ This paper is a first report on an investigation of the corrosion behaviours of the $\mathrm{Fe}-24 \mathrm{Cr}-6 \mathrm{~V}$ alloy system containing $\mathrm{Ru}$ additions in non-oxidizing acid solutions by means of the electrochemical and the AES techniques.

\section{Experimental Procedure}

\subsection{Preparation of the Alloys}

The Fe-24Cr-6V $(0-0.3) \mathrm{Ru}$ alloys were melted in a vacuum induction furnace under an Ar protective atmosphere. The cast ingots were subsequently hotrolled into plates of about $8 \mathrm{~mm}$ thickness. The chemical compositions of the alloys investigated are listed in Table 1. For the purpose of comparison, the $\mathrm{Fe}-24 \mathrm{Cr}$ alloy containing no $\mathrm{V}$ and $\mathrm{Ru}$ was also prepared.

\subsection{Weight-loss Measurements}

Specimen coupons of $\sim 20 \mathrm{~mm} \times 20 \mathrm{~mm} \times 6 \mathrm{~mm}$ were cut from the plates for immersion weight-loss tests. The coupons were heat-treated at $1200^{\circ} \mathrm{C}$ for $2 \mathrm{~h}$ followed by quenching in water. They were wet ground with $\mathrm{SiC}$ paper down to 800 grit, rinsed with distilled water, isopropanol, and weighed. Immersion weight-loss tests were performed in $5 \%$ sulphuric and $5 \%$ hydrochloric acid solutions at temperatures of 70 and $98^{\circ} \mathrm{C}$, respectively. The test solutions were deaerated with $\mathrm{N}_{2}$ during the immersion tests at $70^{\circ} \mathrm{C}$. Duplicate coupons were placed in a glass cradle immersed in a $2 l$ Erlenmeyer flask containing about $1.6 l$ of solution. The flask was fitted with an Allihn condenser. Tests were run for a period of $4 \mathrm{~h}$ in $5 \% \mathrm{H}_{2} \mathrm{SO}_{4}$ solutions at $70^{\circ} \mathrm{C}$. However, the test period was reduced to $30 \mathrm{~min}$ in the above solution at $98^{\circ} \mathrm{G}$. On the other hand, the immersion time of the coupons in $5 \% \mathrm{HGl}$ solution at 70 and $98^{\circ} \mathrm{C}$ were 45 and $30 \mathrm{~min}$, respectively, due to the aggressiveness

Table 1. Chemical compositions of the alloys investigated. (\%)

\begin{tabular}{cccccccc}
\hline \multirow{2}{*}{$\begin{array}{c}\text { Al- } \\
\text { loys }\end{array}$} & \multicolumn{8}{c}{ Elements } \\
\cline { 2 - 8 } & $\mathrm{C}$ & $\mathrm{N}$ & $\mathrm{O}$ & $\mathrm{Cr}$ & $\mathrm{V}$ & $\mathrm{Ru}$ & $\mathrm{Fe}$ \\
\hline 1 & 0.010 & 0.001 & 0.07 & 24.00 & - & - & Balance \\
2 & 0.012 & 0.003 & 0.10 & 24.00 & 6.08 & - & Balance \\
3 & 0.011 & 0.003 & 0.10 & 24.30 & 6.20 & 0.12 & Balance \\
4 & 0.011 & 0.002 & 0.11 & 24.00 & 6.30 & 0.24 & Balance \\
5 & 0.011 & 0.002 & 0.11 & 23.80 & 6.50 & 0.35 & Balance \\
\hline
\end{tabular}

of the solutions. After the immersion tests, the coupons were cleaned with a nylon brush, rinsed with distilled water and weighed.

\subsection{Potentiodynamic Measurements}

Polarization tests were carried out in a deaerated $5 \% \mathrm{HCl}$ acid solution at 25 and $70^{\circ} \mathrm{C}$, respectively by using a Princeton Applied Research (PAR) model 273 potentiostat. The test specimens were cut from the solution-treated coupons in the form of a disc with $11 \mathrm{~mm}$ diameter and $4 \mathrm{~mm}$ thickness. They were wet ground with $\mathrm{SiC}$ paper down to 800 grit, cleaned ultrasonically in distilled water, and then immersed immediately in the test solutions. Before each measurement, the sample was cathodically reduced at $-800 \mathrm{mV}$ for $5 \mathrm{~min}$ in order to remove the air-formed oxide on the sample. The potentiodynamic scan was then initiated at this cathodic potential and scanned continuously to $1300 \mathrm{mV}$ at $1 \mathrm{mV} / \mathrm{s}$. All the potentials cited in this paper are referred to a saturated calomel electrode (SCE).

\subsection{Potential-Time Response Measurements}

Potential-time response measurements were carried out in a $5 \% \mathrm{HCl}$ solution at $25^{\circ} \mathrm{C}$. The working electrode was reduced cathodically at $-800 \mathrm{mV}$ for 5 min. After cathodic reduction, the specimen was allowed to passivate spontaneously. The variation of the potential with time was recorded. The spontaneously passivated surfaces were subsequently analysed in the AES spectrometer.

\subsection{AES Measurements}

AES was carried out in a Varian ultra-high vacuum chamber equipped with a Physical Electronic Industries model 15-110 A cylindrical mirror analyser. The spectrometer was operated at a primary electron beam of $5 \mathrm{keV}$ and a current of $2 \mu \mathrm{A}$ with a peak-to-peak modulation of $3 \mathrm{eV}$. Sputtering was performed using an argon ion gun at $2 \mathrm{keV}$ with a current density of $7 \mu \mathrm{A} / \mathrm{cm}^{2}$ and at a pressure of $3.5 \times 10^{-5}$ Torr. A sputter rate of about $4 \AA / \mathrm{min}$ was obtained under these conditions by using a $\mathrm{Ta}_{2} \mathrm{O}_{5}$ sample of known thickness. Auger depth profiles were obtained by measuring peak-to-peak heights (pph) of the constituent elements in the spontaneously passivated film, with the exception of the $\mathrm{Cr}$ peak. This is because the $\mathrm{O}(510 \mathrm{eV})$ peak interferes with the $\mathrm{Cr}(529 \mathrm{eV})$ peak. It has been reported that the background to negative excursion for the $\mathrm{Cr}(529 \mathrm{eV})$ peak gives a corrected $\mathrm{Gr}$ content in the $\mathrm{Fe}-\mathrm{Gr}$ alloys. ${ }^{20,21)}$ Hence the background to negative excursion for $\operatorname{Cr}$ (529 $\mathrm{eV})$ peak was measured for depth profiling purpose.

\section{Results and Discussion}

\subsection{Immersion Weight-loss Results}

The results of the weight-loss measurements in $5 \% \mathrm{H}_{2} \mathrm{SO}_{4}$ and $5 \% \mathrm{HCl}$ acid solutions are listed in Tables 2 and 3, respectively. It can be seen in Table 2 that the alloys investigated containing $\mathrm{Ru}$ additions exhibit satisfactory performanances in sulphuric acid 
Table 2. Corrosion rates ( $\mathrm{mm} /$ year) of the alloys investigated immersed in $5 \% \mathrm{H}_{2} \mathrm{SO}_{4}$ solution at boiling temperature $\left(98^{\circ} \mathrm{C}\right)$ and at $70^{\circ} \mathrm{C}$, respectively.

\begin{tabular}{lccccc}
\hline \multirow{2}{*}{ Corrosion rates } & \multicolumn{5}{c}{ Alloy } \\
\cline { 2 - 6 } & 1 & 2 & 3 & 4 & 5 \\
\hline Boiling solution & 32292 & 3218 & W.G. & W.G. & W.G. \\
$70^{\circ} \mathrm{G}$ solution & 1225 & W.G. & W.G. & W.G. & W.G. \\
\hline
\end{tabular}

Note: W.G. implies the samples passivated in the test solutions and showed net weight-gains after the immersion tests.

Table 3. Corrosion rates (mm/year) of the alloys investigated immersed in $5 \% \mathrm{HCl}$ solution at boiling temperature $\left(98^{\circ} \mathrm{C}\right)$ and at $70^{\circ} \mathrm{C}$, respectively.

\begin{tabular}{lccrrr}
\hline \multirow{2}{*}{ Corrosion rates } & \multicolumn{5}{c}{ Alloy } \\
\cline { 2 - 6 } & 1 & \multicolumn{1}{c}{2} & \multicolumn{1}{c}{3} & \multicolumn{1}{c}{4} \\
\hline Boiling solution & 5247 & 4830 & 6656 & 532 & 166 \\
$70^{\circ} \mathrm{C}$ solution & 1667 & 1077 & 317 & 44 & 19 \\
\hline
\end{tabular}

solution at both test temperatures. These samples passivated in the sulphuric acid solutions upon immersion and shows no evidence of active dissolution during the test periods. The alloy 2 containing no $\mathrm{Ru}$ exhibits corrosion resistance to $5 \% \mathrm{H}_{2} \mathrm{SO}_{4}$ solution only at a lower test temperature $\left(70^{\circ} \mathrm{C}\right)$ whereas the alloy 1 shows the greatest dissolution in sulphuric acid solution at both test temperatures as expected. On the other hand, the addition of $\mathrm{Ru}$ to the $\mathrm{Fe}-$ $24 \mathrm{Gr}-6 \mathrm{~V}$ alloy system was found to be beneficial at concentration levels of 0.24 and $0.35 \%$, respectively in boiling $5 \% \mathrm{HCl}$ solution. Addition of $0.12 \% \mathrm{Ru}$ was observed to exhibit a slightly beneficial effect in $5 \% \mathrm{HCl}$ solution only at a test temperature of $70^{\circ} \mathrm{C}$. On the basis of these results, it appears that additions of 0.24 and $0.35 \% \mathrm{Ru}$ to the $\mathrm{Fe}-24 \mathrm{Cr}-6 \mathrm{~V}$ based alloy are very effective to promote spontaneous passivation in non-oxidizing sulphuric and hydrochloric acid solutions. Because the $\mathrm{Fe}-24 \mathrm{Gr}-6 \mathrm{~V}$ alloy system exhibits higher weight-loss in $\mathrm{HGl}$ solution than that in $\mathrm{H}_{2} \mathrm{SO}_{4}$ solution, attention is focussed on the corrosion behaviour of this system in $\mathrm{HCl}$ solution.

\subsection{Effect of $\mathrm{Ru}$ on the Corrosion Potentials of the $\mathrm{Fe}-$ $24 \mathrm{Gr}-6 \mathrm{~V}$ Based Alloys}

Fig. 1 shows typical potential-time response curves for the alloys investigated in $5 \% \mathrm{HCl}$ solution at $25^{\circ} \mathrm{C}$. For the $\mathrm{Fe}-24 \mathrm{Cr}-6 \mathrm{~V}$ alloy containing no $\mathrm{Ru}$, the initial potential was located at $-560 \mathrm{mV}$ and it then shifted slightly to $-552 \mathrm{mV}$ after immersion for $100 \mathrm{~s}$. After this period, the potential gradually shifted to original value and remained in this vicinity region for extended period of time. However, addtion of $0.12 \% \mathrm{Ru}$ resulted in a displacement of the corrosion potential of the $\mathrm{Fe}-24 \mathrm{Cr}-6 \mathrm{~V}$ alloy in the noble direction as a function of time. This implies that small amount of $\mathrm{Ru}$ alloying element causes spontaneous passivation to occur in the $\mathrm{Fe}-24 \mathrm{Cr}-6 \mathrm{~V}$ alloy. The transition time for spontaneous passiva-

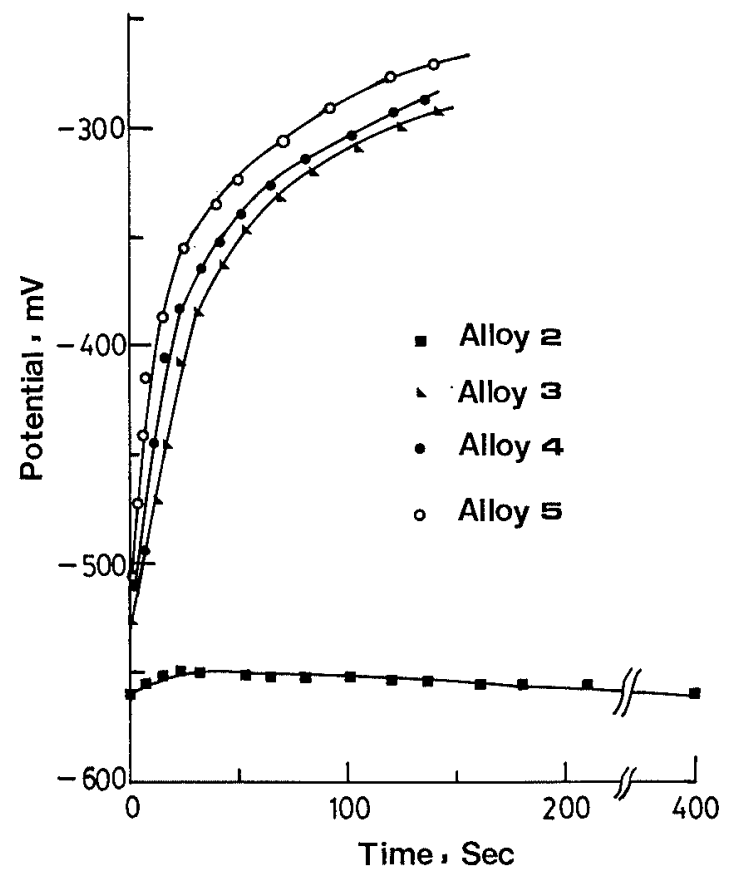

Fig. 1. Potential-time responses for the $\mathrm{Fe}-24 \mathrm{Cr}-6 \mathrm{~V}-\mathrm{Ru}$ alloy system in $5 \% \mathrm{HCl}$ solution at $25^{\circ} \mathrm{C}$.

tion for this sample is about $14 \mathrm{~s}$. Increasing $\mathrm{Ru}$ contents to 0.24 and $0.35 \%$ leads to a substantial decrease in the transition time for spontaneous passivation.

\subsection{Potentiodynamic Results}

Figs. 2(a) and 2(b) show the potentiodynamic curves for the alloys investigated in $5 \% \mathrm{HCl}$ solution at 25 and $70^{\circ} \mathrm{C}$, respectively. From Fig. 2(a), one can see that the alloy 2 exhibits typical active-passive transition characteristics with a high critical current density for passivation $\left(\sim 5 \times 10^{4} \mu \mathrm{A} / \mathrm{cm}^{2}\right)$. The addition of up to $0.35 \% \mathrm{Ru}$ decreased the critical current density for passivation dramatically to a value of $3 \times 10^{2} \mu \mathrm{A} / \mathrm{cm}^{2}$. On the other hand, the active-passive transition in the polarization curves tends to diminish for the $\mathrm{Fe}-24 \mathrm{Cr}-6 \mathrm{~V}$ alloys containing $\mathrm{Ru}$ additions tested in $5 \% \mathrm{HCl}$ solution at $70^{\circ} \mathrm{C}$. Furthermore, the corrosion potentials of $\mathrm{Ru}$ containing alloys were shifted to a more positive value of $\sim-250$ $\mathrm{mV}$; the current densities in the passive region for $\mathrm{Ru}$ containing alloys are about two orders of magnitude smaller than those of $\mathrm{Ru}$-free $\mathrm{Fe}-24 \mathrm{Gr}-6 \mathrm{~V}$ alloy. Hence $R u$ is very effective in promoting spontaneous passivation of the $\mathrm{Fe}-24 \mathrm{Cr}-6 \mathrm{~V}$ alloy, thereby reducing the anodic dissolution of this alloy in hydrochloric solution.

\subsection{AES Spectra and Composition Depth-profiles}

Figs. 3(a) and 3(b) show the AES spectra of the spontaneously formed film on the alloy 5 in $5 \% \mathrm{HGl}$ solution at $25^{\circ} \mathrm{C}$ before sputtering and after sputtering for $6 \mathrm{~min}$, respectively. The Auger spectrum of the film before sputtering shows the presence of alloying elements $\mathrm{V}$ and $\mathrm{Cr}$, but does not show $\mathrm{Ru}$. It is known that the spectrum of pure $\mathrm{V}$ shows three principal Auger peaks located at 437,473 and $509 \mathrm{eV} .{ }^{22}$ ) 
(a)

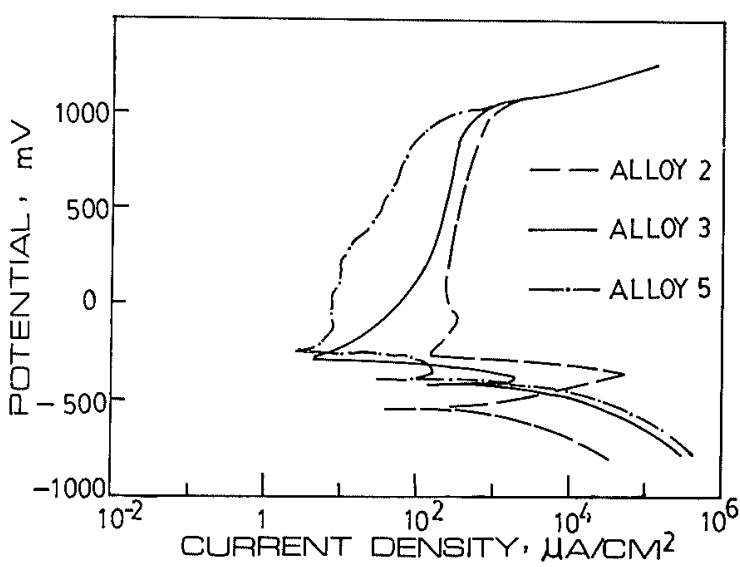

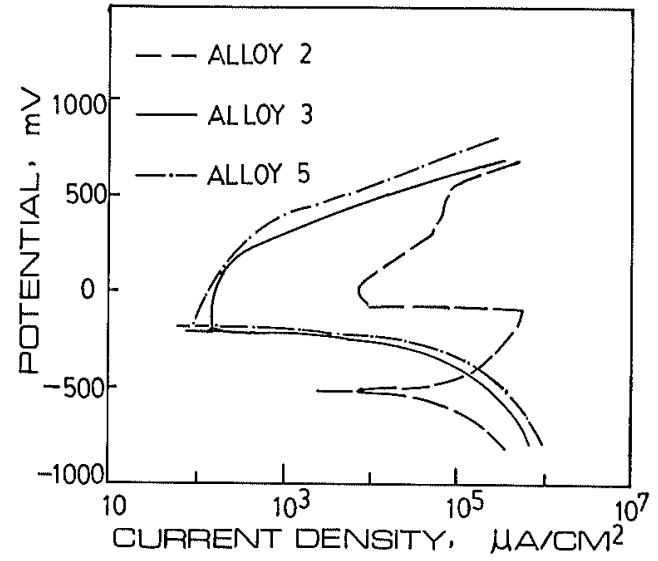

Fig. 2. Potentiodynamic curves for the alloys 2, 3, and 5 in $5 \% \mathrm{HCl}$ solution at (a) $25^{\circ} \mathrm{C}$ and (b) $70^{\circ} \mathrm{C}$.

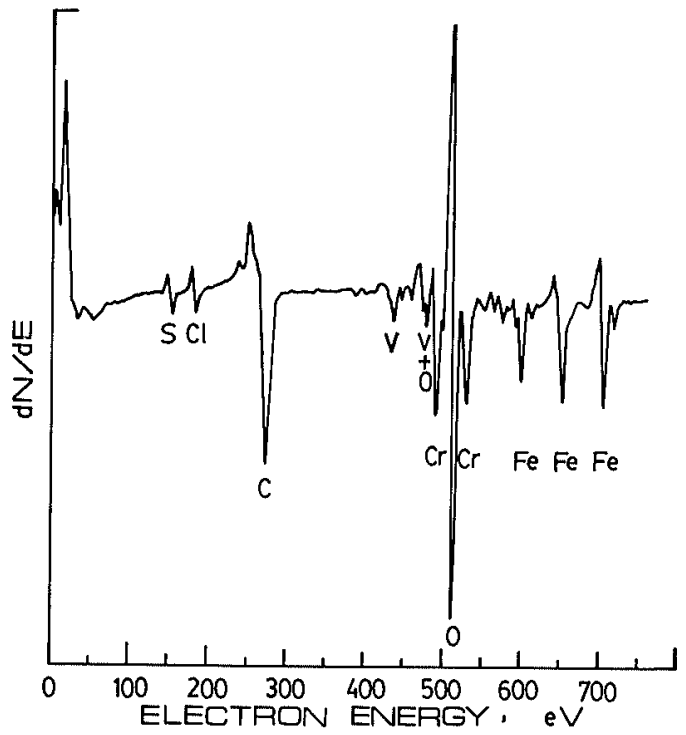

(a) Before sputtering

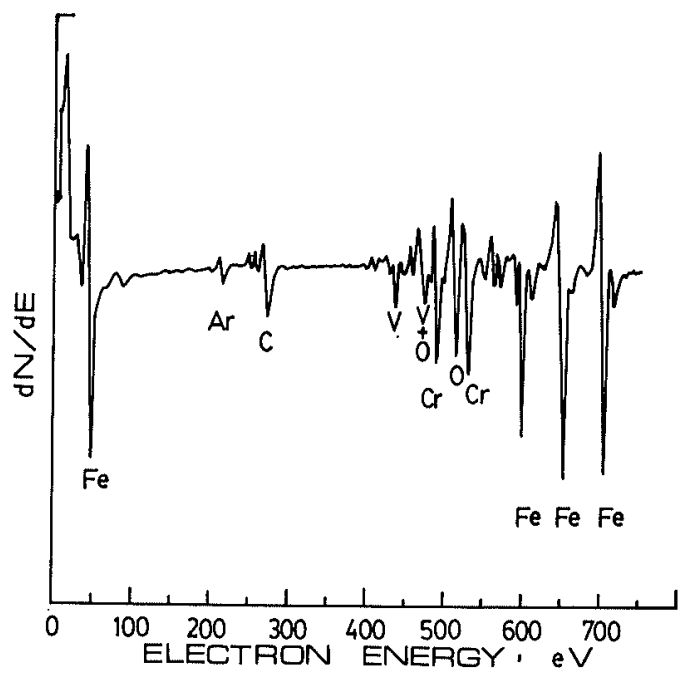

(b) After sputtering for $6 \mathrm{~min}$

Fig. 3. Auger spectra for the Fe-24Cr-6V-0.3Ru alloy passivated spontaneously in $5 \% \mathrm{HCl}$ solution at $25^{\circ} \mathrm{C}$.

The strongest $\mathrm{V}$ peak at $473 \mathrm{eV}$ tends to interfere with the $\mathrm{O}$ peak located at $468 \mathrm{eV}$, whereas the smallest principal $\mathrm{V}$ peak at $509 \mathrm{eV}$ tends to interfere

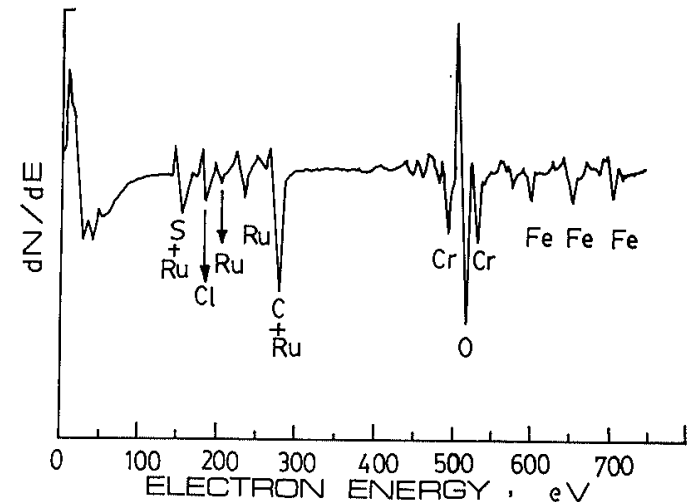

Fig. 4. Auger spectrum for the $\mathrm{Fe}-40 \mathrm{Cr}-0.2 \mathrm{Ru}$ alloy passivated spontaneously in $0.5 \mathrm{M} \mathrm{HCl}$ solution at $25^{\circ} \mathrm{C}$ before sputtering.

with the strongest $\mathrm{O}$ peak located at $510 \mathrm{eV}$. Hence the $\mathrm{V}$ peak at $473 \mathrm{eV}$ is used for the depth profiling measurements. On the other hand, the spectrum of pure Ru shows 4 strong principal Auger peaks located at $150,200,231$, and $273 \mathrm{eV}$, respectively. ${ }^{22)}$ The strongest $\mathrm{Ru}$ peak at $273 \mathrm{eV}$ interferes with the principal peak for $\mathrm{C}$ located at $272 \mathrm{eV}$, and the $\mathrm{Ru} 150$ $\mathrm{eV}$ tends to interfere with the $\mathrm{S}$ peak located at 152 $\mathrm{eV}$. It is interesting to see that $\mathrm{Ru}$ is not detected in the spontaneously passivated film formed on the Alloy 5. For the purpose of comparison, the AES spectrum of the spontaneously passivated film formed on the $\mathrm{Fe}-40 \mathrm{Cr}-0.2 \mathrm{Ru}$ alloy in $0.5 \mathrm{M} \mathrm{HCl}$ solution at $25^{\circ} \mathrm{G}$ before sputtering is shown in Fig. 4. It can be seen that $\mathrm{Ru}$ was present in the spontaneously passivated film formed on the $\mathrm{Fe}-40 \mathrm{Cr}-0.2 \mathrm{Ru}$ alloy.

Tomashov et al. reported that the initial dissolution of $\mathrm{Cr}$ into solution from $\mathrm{Cr}$ alloys containing PGM additions resulted in the formation of PGM adatoms since the PGM atoms lose their bond to adjacent $\mathrm{Cr}$ atoms. The PGM adatoms were then diffused to the surface defect sites of the lattice, e.g., kinks, and subsequently blocked and accumulated in these sites. Hence the active dissolution of Cr from the Cr alloy becomes lower. The blocking PGM atoms led to the spontaneous passivation of the $\mathrm{Cr}$ alloys due to their low overvoltage for hydrogen evolution. ${ }^{23)}$ For this reason, $\mathrm{Ru}$ was detected if the film formed on 
the $\mathrm{Fe}-40 \mathrm{Cr}-0.2 \mathrm{Ru}$ alloy.

From the above discussion, the absence of $\mathrm{Ru}$ in the spontaneously passivated film formed on the $\mathrm{Fe}-$ $24 \mathrm{Cr}-6 \mathrm{~V}-\mathrm{Ru}$ alloy system can be explained in terms of the competition between $\mathrm{V}$ and $\mathrm{Ru}$ in blocking the surface defect sites of the lattice. The concentration of $\mathrm{V}$ in bulk alloy 5 is 20 times greater than that of $\mathrm{Ru}$. Hence most of the surface defect sites are blocked by $\mathrm{V}$ rather than $\mathrm{Ru}$ atoms. Spontaneous passivation occurs when the surface concentration of $\mathrm{Ru}$ reaches a critical value. $\mathrm{Ru}$ can be detected by the AES, provided that there is an enrichment of this element in the passive surface similar to that in the $\mathrm{Fe}-40 \mathrm{Cr}-0.2 \mathrm{Ru}$ alloy.

Fig. 5 shows the Auger depth-profile of the alloy 5 spontaneously passivated in $5 \% \mathrm{HGl}$ solution at $25^{\circ} \mathrm{C}$. The thickness of the passive film can be estimated from the $\mathrm{O}$ profile where the oxygen amplitude has reduced to half its maximum amplitude and the sputter rate was assumed to be correlated with that of $\mathrm{Ta}_{2} \mathrm{O}_{5}$. In this case, the thickness of the film is estimated to be $\sim 18 \AA$. In this figure, $\mathrm{Cr}$ and $\mathrm{V}$ signals are low at the surface of the passive film and they pass through an apparent maximum in the film. The normalized $(\mathrm{Cr} /(\mathrm{Fe}+\mathrm{Cr}+\mathrm{V})$ and $\mathrm{V} /(\mathrm{Fe}+\mathrm{Cr}+\mathrm{V}))$ Auger peak-to-peak heights ratios vs. the amount of film removed by sputtering for the spontaneously passivated film formed on the alloy 5 is shown in Fig. 6 . It can be seen that both $\mathrm{Gr}$ and $\mathrm{V}$ are enriched in the spontaneously passivated film. The enrichment of $\mathrm{Cr}$ in the passive film is generally known to be responsible for an increase in the corrosion resistance of the $\mathrm{Fe}-\mathrm{Cr}$ alloys. Thus the beneficial effect of $\mathrm{V}$ addition on the corrosion resistance can be explained by the enrichment of this element in the passive film. $\mathrm{V}$ and Mo are known to exhibit similarity in corrosion be- haviour brought about by alloying due to their adjacent positions in the periodic table. Both elements exhibit beneficial effects on pitting corrosion resistance of the ferritic stainless steels, although $\mathrm{V}$ was not as effective as Mo.6,9) Furthermore, Mo was enriched in the passive films formed on the $\mathrm{Fe}-\mathrm{Cr}-\mathrm{Mo}$ alloys at low potentials in the active region and at low potentials in the passive region. ${ }^{18,24)}$ Similarly, the concentration of $\mathrm{V}$ in the films formed on the $\mathrm{Fe}-\mathrm{Cr}-\mathrm{V}$ alloy at high potentials in the passive region is lower than that formed in the cathodic region. ${ }^{91}$ Fig. 7 shows the normalized $(\mathrm{Cr} /(\mathrm{Fe}+\mathrm{Cr}+\mathrm{V})$ and $\mathrm{V} /(\mathrm{Fe}+$ $\mathrm{Gr}+\mathrm{V})$ ) Auger peak-to-peak height ratios vs. sputtering time for the spontaneously passivated film formed on the alloy 3. Similar enrichment characteristics are observed in the spontaneously passivated film formed on the alloy 3 in $5 \% \mathrm{HCl}$ solution at $25^{\circ} \mathrm{C}$.

\section{Conclusions}

(1) Weight-loss measurements show that $\mathrm{Fe}-$ $24 \mathrm{Cr}-6 \mathrm{~V}$ alloys containing $0.12-0.35 \% \mathrm{Ru}$ exhibit good corrosion resistance in boiling $5 \% \mathrm{H}_{2} \mathrm{SO}_{4}$ solution and also in $5 \% \mathrm{H}_{2} \mathrm{SO}_{4}$ solution at $70^{\circ} \mathrm{C}$. However, the addition of $\mathrm{Ru}$ to the above based alloy is only found to be beneficial at concentration levels of 0.24 and $0.35 \%$, respectively, in $5 \% \mathrm{HCl}$ solution at $70^{\circ} \mathrm{C}$ and at boiling temperature.

(2) Potentiodynamic measurements indicate that addition of $\mathrm{Ru}$ to the $\mathrm{Fe}-24 \mathrm{Cr}-6 \mathrm{~V}$ based alloy is effective in decreasing the critical current density for passivation, and in promoting spontaneous passivation in $5 \% \mathrm{HCl}$ solution by shifting the corrosion potential towards the noble direction.

(3) AES spectra reveal that the spontaneously passivated films formed on the Fe-24Cr-6V-Ru alloy system are depleted of $\mathrm{Ru}$. However, the composition depth-profiles show that enrichment of $\mathrm{Cr}$ and $\mathrm{V}$ occurs in the spontaneously passivated films formed on this system.

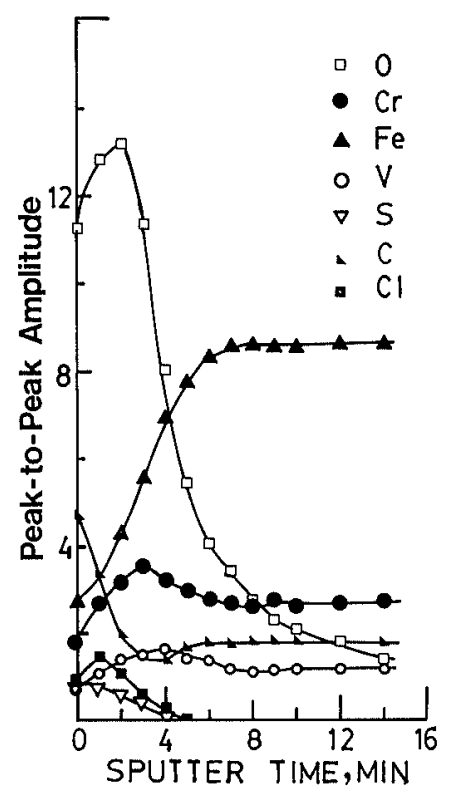

Fig. 5.

Auger depth-profile for the $\mathrm{Fe}-24 \mathrm{Cr}$ $6 \mathrm{~V}-0.3 \mathrm{Ru}$ alloy passivated spontaneously in $5 \% \mathrm{HCl}$ solution at $25^{\circ} \mathrm{C}$.

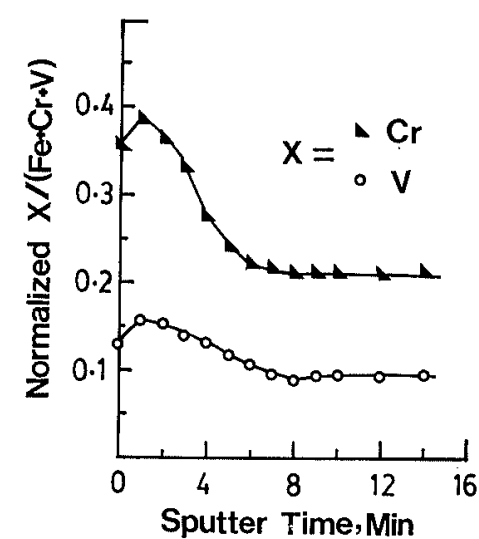

Fig. 6 .

Normalized Auger peak height ratios $(\mathrm{Cr} /(\mathrm{Fe}+\mathrm{Cr}+\mathrm{V})$ and $\mathrm{V} /(\mathrm{Fe}+\mathrm{Cr}+$ V)) vs. sputtering time for the passivated film spontaneously formed on the $\mathrm{Fe}-24 \mathrm{Cr}-6 \mathrm{~V}-0.3 \mathrm{Ru}$ alloy in $5 \%$ $\mathrm{HCl}$ solution at $25^{\circ} \mathrm{C}$.

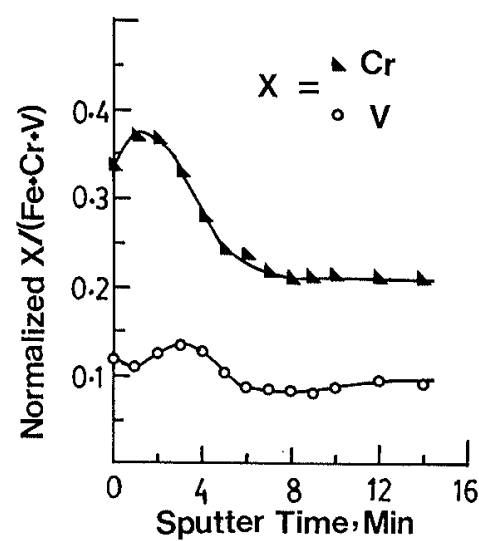

Fig. 7.

Normalized Auger peak height ratios $(\mathrm{Cr} /(\mathrm{Fe}+\mathrm{Cr}+\mathrm{V})$ and $\mathrm{V} /(\mathrm{Fe}+\mathrm{Cr}+$ $\mathrm{V})$ ) vs. sputtering time for the passivated film spontaneously formed on the $\mathrm{Fe}-24 \mathrm{Cr}-6 \mathrm{~V}-0.1 \mathrm{Ru}$ alloy in $5 \%$ $\mathrm{HCl}$ solution -at $25^{\circ} \mathrm{C}$. 


\section{Acknowledgements}

This work is published by permission of the Council for Mineral Technology in Randburg. The author would like to thank M. Kincer, Council for Mineral Technology, for assistance in potentiodynamic and weight-loss measurements. $\mathrm{He}$ also wishes to thank Prof. J. B. Malherbe of the Department of Physics, University of Pretoria for the provision of Auger facilities.

\section{REFERENCES}

1) W. O. Binder and H. R. Spendelow, Jr.: Trans. Am. Soc. Met., 43 (1951), 759.

2) E. A. Lizlova and A. P. Bond: J. Electrochem. Soc., 116 (1969), 574.

3) J. N. Wanklyn: Corros. Sci., 21 (1981), 211.

4) C. Aslund: Stainless Steel 77, ed. by R. Q. Barr, Climax Molybdenum Co., Greenwich, CT, (1977), 173-176.

5) F.P.A. Robinson and P. Van Biljon: Corrosion, 41 (1985), 220.

6) R. D. Davies and F.P.A. Robinson: Corrosion, 45 (1989), 337.

7) M. S. Walker and L. C. Rowe: Corrosion, 25 (1969), 47.

8) G. J. Biefer: Can. Met. Quart., 9 (1970), 537.

9) G. Goetz, J. Laurent and D. Landolt: Corros. Sci., 25 (1985), 1115.

10) N. D. Tomashov, G. P. Ghernova, L. N. Volkov, A.P. Zakharov and Z. E. Sheshina: Prot. Met., 9 (1974), 289.
11) G. P. Chernova, N. D. Tomashov and L. A. Chigirinskaja: Corrosion, 34 (1978), 445.

12) M. A. Streicher: Corrosion, 30 (1974), 77

13) M. A. Streicher: Platinum Met. Rev., 21 (1977), 51.

14) G. G. Robson: Platinum 1987, Johnson Matthey Co. London, (1987), 49-54.

15) G. P. Chernova, L. A. Ghigirinskaja, N. D. Tomashov and E. A. Nasedkina: Prot. Met., 22 (1986), 704.

16) G. P. Chernova, O. D. Agakishiev and N. D. Tomashov: Proc. 10th Int. Congress on Metallic Corrosion, Madras, India, II, (1987), 1659-1670.

17) K. Asami, K. Hashimoto and S. Shimodaira: Corros. Sci., 18 (1978), 151.

18) K. Hashimoto, K. Asami and K. Teramoto: Corros. Sci., 19 (1979), 3.

19) S. C. Tjong, R. W. Hoffman and E. B. Yeager: J. Electrochem. Soc., 129 (1982), 1662.

20) W.L.N. Matthews, P.J.K. Paterson and H. K. Wagenfeld: Appl. Surf. Sci., 15 (1983), 281.

21) S. G. Tjong, J. Eldridge and R. Hoffman: Appl. Surf. Sci., 14 (1982), 297.

22) L. E. Davis, N. D. MacDonald, P. W. Palmberg, G. E. Riach and R. E. Weber: Handbook of Auger Electron Spectroscopy, 2nd ed., Physical Electronic Industries, Eden Prairie, MN, (1976), 75, 135.

23) N. D. Tomashov, G. P. Chernova and E. N. Utinski: Corrosion, 40 (1984), 134.

24) R. Goetz and D. Landolt: Electrochim. Acta, 19 (1984), 667. 